By ARTHUR T. HAMLIN

\title{
The ACRL Grants for 1956
}

$\mathrm{T}$ he Association of College and Reference Libraries has on hand $\$ 40$,000 in three separate grants which will be distributed as subgrants to college and university libraries this fall. This article has been prepared to give precise information on the funds now in hand for distribution, the types of institutions which these funds are designed to assist, the procedure for the distribution of application forms and their processing, and the general purposes which grants are designed to support. The experience of the past year in raising money for the grants program is summarized.

A grant of $\$ 30,000$ from the United States Steel Foundation represents the principal sum available this fall. Approximately $\$ 25,000$ will be allotted in subgrants to college and university libraries for the improvement of their collections, equipment and programs as adjuncts to the teaching and learning processes. Most of the remainder is available for professional research of benefit to college librarianship.

A grant of $\$ 5,000$ from the New York Times is limited to the purchase of back files of the newspaper on microfilm. A grant of $\$ 5,000$ from Remington Rand, a division of the Sperry Rand Corp., is to be used for library equipment.

\section{Eligibility}

Applications for 1956 grants are invited from institutions which offer four

Mr. Hamlin, who has just retired as ACRL Executive Secretary, is librarian of the University of Cincinnati and new chairman of the ACRL Committee on Foundation Grants. years of undergraduate instruction and which have little or no tax support. Scientific institutions are included. Only those junior colleges which are planning four-year programs in the near future are invited to apply. The great universities and colleges which are unusually well blessed with endowment or other large special sources of income are discouraged from seeking these funds. Institutions which receive major support from a religious, fraternal or social organization and which limit their student body to that organization are likewise unlikely to receive favorable consideration. If the student body is not so limited, the institution is eligible for support.

Inevitably some will ask for an exact definition of "a great university" or "little tax support." This the writer cannot supply. Any institution may apply. Last year grants went to the Catholic University of America and to Atlanta University, which are apparently the largest institutions on the list. Berea College received assistance in 1955, and this institution certainly is "well blessed with endowment." However, Berea does not charge tuition and its student body is drawn only from low income families.

A small number of 1955 applications for United States Steel Foundation grants were eliminated because the institutions had very poor records of library support in recent years. Here again exact definition is difficult. The Committee on Foundation Grants felt that institutions should budget for library purposes at least 4 per cent of funds available for educational and general purposes, as defined by the U. S. Office of Education. This need not be done 
every year, but the average of recent budgets should reach that level. Behind this decision was the realization that the amount to be distributed was small and preference should be given to the majority of colleges which recognize the importance of the library in their budgets. Four per cent is much too low for many institutions; it may be higher than necessary for a very few institutions. The committee always made allowance for the donated time of librarians in orders and for similar factors. It is, therefore, urged that institutions which apply for grants and which do not meet that standard state the cirsumstances or reasoning responsible for low library support.

Although the application form requests information on membership in ALA, the 1955 awards were not prejudiced by lack of membership. No change is expected in 1956. The Association does, however, need support. Last year it invested a considerable portion of its reserve funds in the grants program. This money comes from the annual fees paid by individual and institutional members.

These limitations on the award of United States Steel Foundation and other grants at the Association's disposal are suggestive only. An extraordinary need or an exceptionally imaginative proposal will be carefully considered regardless of committee policy on eligibility. If any one of these limitations is considered to work an injustice on any institution, it is invited to submit an application. Exceptional cases will be considered on their merit.

\section{Procedures of Application}

The Association will mail out application forms to nearly six hundred four-year, non-tax-supported institutions early in October. These will be addressed to the librarian. Inevitably some eligible and interested colleges will be skipped or suffer from mail or clerical error. If the form has not been received by October 20, a request for it should be sent at once to ACRL headquarters. Two forms are sent to every addressee, one for return and one for retention.

Applications are due at ACRL headquarters on or about the middle of November. Late in the month the Committee on Foundation Grants will meet for several days in Chicago to study the applications and select those most suitable for grants. All applications will be answered, and those institutions which receive grants should have checks in hand early in January.

\section{Purposes of Grants}

In planning the 1956 grants program the committee established several broad purposes for which applications are invited and determined approximate division of funds among these. This statement is intended to discourage, but not to eliminate, applications for needs not here represented. Institutions may make several requests in one application but cannot hope for more than one grant.

A large portion of the United States Steel Foundation grant is allocated for the purchase of books, journals, and related materials for instruction and the learning process. Of special interest will be situations where particular, urgent library support is required to carry on instruction in a new field or at an advanced stage (below doctoral level), or where there is evidence that a limited sum will otherwise give great assistance to an area of instruction or of worthy student interest. The committee is as much interested in the statement of objective as in the materials needed. Only in cases of extraordinary need or disaster will grants be made for general strengthening of the book collection. Special consideration will be given to cooperative programs of ownership of 
books and related materials by neighboring colleges.

The phrase "books and related materials" may be interpreted very broadly. Materials should, however, be suitable for undergraduate use. Projects involving strictly research materials are not encouraged in this program. The project need not involve classroom instruction. For example, one 1955 grant was made for dormitory libraries and several others supported the learning process apart from the curriculum. Very few allocations will be made for special staff help required to make materials useful.

Most of the grants for "books and related material" will range from $\$ 300$ to $\$ 500$. None is expected to be in excess of $\$ 1,000$.

All of the Remington Rand grant $(\$ 5,000)$ will be used for furniture and equipment which is available through their Library Bureau. Applications should specify items needed by catalog number. Most or all of these grants will be from $\$ 400$ to $\$ 600$. A very small portion of the United States Steel Foundation funds may be used for equipment.

It is recommended that applications for equipment avoid items which are the responsibility of the annual budget. To illustrate, the typewriter for the librarian's secretary should be purchased with college funds, but the typewriter required for some special, important project is a proper object for a grant. Likewise, furniture for a special room or area may be requested but not standard furniture for a main reading room. The project or need is of primary importance; equipment of any description required for an excellent project may be considered suitable for a grant.

The New York Times grant of $\$ 5,000$ is restricted to the purchase of microfilm back files of this newspaper. Grants will cover the cost of four to six recent years, and will be limited to institutions whose book budgets are sufficiently large to warrant a current subscription to the microfilm edition. No commitment as to current subscription is necessary, but successful applicants will be requested to procure the New York Times Index (printed or microfilm) for the years covered by the grant. The writer regrets inability to state the exact minimum book budget which warrants a New York Times microfilm subscription. Five thousand is undoubtedly too little; eight thousand is sufficient in certain situations; ten thousand is considered a safe figure.

When the New York Times grant was first announced, the librarian of a state college requested consideration for a file. When she was informed that these grants were primarily for privately supported institutions, she replied that there was no New York Times in any library of her medium-sized city; she had been assured that the neighboring private college would apply and, if it received a grant, would make the Times available to both institutions. This particular case is cited to illustrate the type of information which often influences a committee which has a very few awards to make from a great number of worthy applications.

The story of how the Times came to make this grant is of interest. More than a score of the applications received last fall requested funds to buy the New York Times on microfilm. This was reported to Chester Lewis, librarian of the Times. He requested a letter on the subject and brief information on the foundation grants program. In the course of a few weeks the check for this project had been received. There may well be other special needs shared by many libraries which have special interest to a particular corporation. Any suggestions will be appreciated.

Several grants of $\$ 500$ or less may be made to provide libraries with consultant services or to finance the travel and 
study of librarians. The consultant may be needed to examine some aspect of the library's operation or to study its over-all effectiveness. Likewise, a new building or an important change in the curriculum may require travel or shortterm study by a staff member. Travel and study applications should be supported by concrete evidence that the institution needs it for a particular, worthy purpose. Requests for consultants and travel may receive more careful attention if the institution is willing to share the cost.

Very few grants will be made for these purposes, which will appeal to many. Only compelling needs can be financed. The Association hopes to support this type of activity on a much larger scale as the over-all grants program grows in size.

Several thousand dollars from the United States Steel Foundation grant are assigned to support research in library problems which will lead to more effective operation, procedures, and professional tools. Unlike applications for other purposes, requests for funds to finance research should be made at once by letter, accompanied by full description of the project, to Jerrold Orne, Chairman, ACRL Publications Committee, Air University Libraries, Maxwell Air Force Base, Montgomery, Alabama. These applications for research funds will be reviewed by the Publications Committee.

\section{Suggestions for Applicants}

The ACRL grant application form, which will be distributed in early October, requests relatively little information about the institution and the growth and support of its library. The applying institution is then invited to present its case for one or more grants. In this presentation a key factor is the statement of purpose. This must demonstrate that the materials, equipment, or other facility to be financed by the grant will make a direct contribution either to the formal educational program or to the intellectual development of the student.

Some of the applications received last year were for admittedly worthy, general purposes, such as strengthening the reference collection or completing certain serial files. Any steps of that nature certainly strengthen the educational program. However, few such requests were granted because the information about purpose was not sufficiently specific. A request for scientific serials carries weight if reinforced with information about the new chemical industry in the vicinity, the strengthening of the chemistry department, perhaps the addition of new courses, and similar explanation. If, in addition, the Friends of the Library raised three hundred dollars for science last year and the president promises to match any grant from special appropriation or the pocket of a trustee, could any committee turn down the application?

The grants program seeks to place money where it will make the greatest contribution to higher education through the library function. It matters little whether the funds buy steel desks or first editions so long as these objects serve a worthy purpose. These purposes for which grants are made in 1956 will be carefully studied by foundations which are approached for support another year.

\section{Financing the Grants Program}

During the past winter and spring the ACRL Executive Secretary carried the responsibility for soliciting support of the 1956 program in addition to his other duties.

A first step was the preparation of the booklet, A Program for Grants to Assist College Libraries and A Report on the United States Steel Foundation Grant of 1955, by Arthur T. Hamlin, which was issued by the Association. In effect, 
this stated who we were, how we operated, what was accomplished last year, the needs of college libraries and the Association's plans for meeting them. The case for financial support was presented.

This booklet was distributed to library leaders in the expectation that many of them would present this worthy cause to friends, fellow board members and other acquaintances who were officers of corporations and in a position to give financial support. A number of copies were sent to the larger corporate foundations and industries with covering letters. The executive secretary then followed up as many as possible of these contacts with personal interviews, most of which were done on a two-week trip to principal eastern cities.

Nearly every large corporation uses a committee of senior officers to control donations. They determine policy and each member studies all major requests prior to group discussion and action. Most committees have an executive officer who interviews the person presenting a case for support and who often recommends company policy on grants and donations. In many corporations these executive officers are vice presidents; all occupy very responsible posts; a few devote full time to this subject.

These men are extraordinarily well informed on the needs of higher educa- tion and with very few exceptions were willing to devote any amount of time to discussion of library needs and the role of the library. They studied the ACRL presentation carefully before the interview. In one case a vice president devoted a good part of the afternoon to this although the annual stockholders' meeting was then in progress in the building. A call from the president was even postponed.

In many cases the decision to support the ACRL program requires a change in policy, and such changes take time; in other cases corporations prepare annual budgets for their principal grants. For these and other reasons the work done in 1956 may bear fruit another year. Financial support will increase or decline in proportion to the time that the new executive secretary devotes to this work and his talent for this activity.

Whatever the eventful financial return from these activities in 1956, it is a pleasure to report that the college library was the subject of study and prolonged discussion by senior officers of more than a score of corporations. Since these officers are leaders in many different aspects of the life of the nation the college library will benefit in sundry ways from any increase in their knowledge of its present role in higher education and its needs for future development.

\section{Fulbright and Smith-Mundt Awards for 1957-58}

The Department of State has announced awards for graduate study, teaching, lecturing, advanced research, and specialized training and observation for 1957-58 under the Fulbright and Smith-Mundt Acts. Applications are being accepted for awards in Austria, Belgium and Luxembourg, Chile, Denmark, Finland, France, Germany,
Greece, Iraq, Italy, Japan, Netherlands, Norway, and the United Kingdom. For information and application forms address The Executive Secretary, Conference Board of Associated Research Councils, Committee on International Exchange of Persons, 2101 Constitution Avenue, Washington 25, D.C. 